\title{
Discussion: Design for efficient drainage of railway track foundations
}

Ken R. Rushton PhD, DSC, CEng, MICE, MCIWEM Emeritus Professor, School of Engineering, University of Birmingham, Birmingham, UK

\section{Gurmel Ghataora PhD, MIMM, MILT}

Senior Lecturer, School of Engineering, University of Birmingham, Birmingham, UK
Vishnu Diyaljee PhD, PEng, FASCE

Managing Director, GAEA Engineering Ltd, Brampton, Ontario, Canada

\section{Contribution by V. Diyaljee}

Drainage of highway pavements and railway roadbed structures has long being identified as an important attribute in ensuring lasting good performance of these important ground transportation systems. The authors' research work in examining the influence of drainage in railway roadbeds through experimental and numerical studies (Rushton and Ghataora, 2009) has yielded information that has confirmed intuitive thinking about the influence of water on track performance and the need to ensure that water is moved efficiently out of the roadbed.

As understood, the railway roadbed structure investigated experimentally and subjected to numerical modelled consists of one-sized ballast overlying a sand sub-ballast and the subgrade which is considered to be impermeable. No material characteristics have been provided for these layer components such as gradation of the ballast and sand sub-ballast layers, material type, compaction and saturation characteristics of the subgrade soil.

Although these features can be considered to be constants in the overall objectives of the study, the influence of water on the behaviour of the sand sub-ballast and subgrade is equally as important and needs to be addressed as an important aspect of the performance of the sub-ballast and subgrade that is influenced by the presence of water in relation to the stability of these layer components both under static and dynamic loading conditions. For example, the sand sub-ballast layer may be prone to liquefaction under dynamic loads and hence the possible loss of particulate matter owing to its resulting mobility. Without the effect of the dynamic loads, grain mobility can result from seepage flows during drainage under static head. The use of a suitable geotextile between the sub-ballast and ballast would act as a separator and prevent upwards migration of sand fines into the ballast layer and the downwards migration of ballast fouling fines to the sand sub-ballast layer, and accelerate drainage. This geotextile should also be incorporated vertically between the shoulder ballast track support ballast to avoid loss of sand sub-ballast owing to lateral drainage. Loss of sand sub-ballast can result in non-uniform track support and hence impact overall track stability.

Similarly, the subgrade, if cohesive, can be softened leading to decreasing subgrade stiffness and increased plastic deformation of the subgrade, both of which can impact track performance negatively.

Although the study has shown that the use of a gecomposite between the sand sub-ballast and subgrade can enhance drainability of the track structure, it is important that the water does not impact the subgrade and as such a geomembrane inclusion similar to that used in landfills should be used at the base of the drainage geocomposite to avoid water infiltrating the subgrade and hence prevent deterioration of the subgrade.

The comments made are not intended to diminish the importance of the authors' research, but are considered important from a practical viewpoint and to avoid practitioners overlooking these factors.

Overall, the authors' study has brought to light in a clear and concise manner the importance of drainage to the behaviour of railway roadbeds beds and the need to pay careful attention to the influence of water on the performance of this facility by incorporating the authors' findings along with material characteristics of the component road layers in design of track foundations.

\section{Authors' reply}

The authors wish to thank the contributor for the encouraging comments about their paper. Regarding the question about the material characteristics, both the ballast and the sand complied with the Network Rail standards for ballast and blanketing sand. These are described in an earlier paper (Rushton and Ghataora, 2009). The sand layer (also known as the blanketing layer) is compacted in place; its composition is designed to prevent migration of fines from the subgrade to the overlying 
ballast (Network Rail, 1998). Thus, if the sand layer is placed correctly, it will not suffer from liquefaction.

The use of a geotextile as a separating layer between the subballast and the ballast is standard practice if the sub-ballast is a granular materials (such as sand) to prevent ballast from punching into the underlying layer. In terms of a clayey subgrade, careful consideration must be given to the type of geotextile used to ensure that it does not become clogged with clay and then act as a low permeability layer causing a clay slurry to form and migrate into the ballast layer. Some recent specially designed composites prevent migration of fines into the ballast. The use of geosynthetics with sand blankets is described by Sharpe and Caddick (2004).

The suggestion of placing a vertical geotextile requires careful consideration in terms of the need to maintain free flow between the ballast layer, the rails, then into the shoulders and to the drains in the cess area. In addition, it is inevitable that with time, as the ballast degrades, fines will develop in the ballast layer and these will be deposited on the underlying geotextile and on the geotextile in the shoulders (as proposed in the discussion). This will reduce permeabilities and could lead to ponding of water in the lower layers of the ballast.
This may accelerate degradation. Furthermore attention needs to be given to shoulder cleaning. Nonetheless, it is worth considering the use of geocomposite drains in such an application.

In terms of impermeable membranes, caution need to be exercised on two counts. First, a smooth impermeable membrane may create a slip plane in the track substructure construction, which may lead to lateral instability. Second, in the case of cohesive soils, pore water pressure may build up under this layer, leading to increased settlement and possible lateral stability issues.

\section{REFERENCES}

Network Rail (1998) Track Blanketing Sand. Network Rail Group Standards, London, UK, NR/SP/TRK/033.

Rushton KR and Ghataora G (2009) Understanding and modelling drainage of railway ballast. Proceedings of the Institution of Civil Engineers - Transport 162(4): 227-236, http://dx.doi.org/10.1680/tran.2009.162.4.227.

Sharpe P and Caddick VR (2004) http://www.geofabrics.com/ docs/paper $\% 20-\% 20$ sharpe $\% 20$ railway $\% 20$ engineering $\%$ 202004.pdf (accessed 25/08/2015) 